\title{
Konstruksi Bilangan Reproduksi pada Model Epidemik SEIRS-SEI Penyebaran Malaria dengan Vaksinasi dan Pengobatan
}

\author{
ResmaWAn, NuRWAN \\ Jurusan Matematika FMIPA Universitas Negeri Gorontalo \\ Jl. Jenderal Sudirman No.6 Kota Gorontalo, 96128 \\ resmawan@ung.ac.id, nurwan@ung.ac.id
}

\begin{abstract}
Abstrak
Dalam artikel ini dibahas model matematika penyebaran malaria tipe SEIRS-SEI. Modifikasi model dilakukan dengan pemberian perlakuan pada manusia, berupa treatment vaksinasi dan pengobatan. Dalam model ini, populasi manusia dibagi menjadi empat kelas, yaitu rentan, terpapar, terinfeksi, dan pulih. Adapun populasi nyamuk dibagi menjadi tiga kelas, yaitu rentan, terpapar dan terinfeksi. Selanjutnya dilakukan konstruksi bilangan reproduksi $\left(R_{0}\right)$ yang merupakan nilai harapan banyaknya infeksi tiap satuan waktu. $R_{0}$ dalam artikel ini ditentukan dengan menggunakan pendekatan matriks generasi mendatang. Pada bagian akhir dalam artikel ini diberikan simulasi numerik untuk menunjukkan efektifitas vaksinasi dan pengobatan pada manusia untuk menekan laju penularan penyakit. Hasil simulasi menunjukkan bahwa peningkatan efektifitas vaksinasi maupun pengobatan pada manusia mampu menurunkan bilangan reproduksi. Hal tersebut menunjukkan bahwa jumlah individu yang terinfeksi semakin berkurang dan dalam jangka waktu tertentu penyakit akan menghilang dari populasi.
\end{abstract}

Kata kunci:Bilangan Reproduksi, Model Malaria, SEIRS-SEI , Vaksinasi, Pengobatan.

\begin{abstract}
This article discusses the mathematical model of SEIRS-SEI type malaria spread. Modification of the model is done by giving the treatment in humans, in the form of vaccination and medication treatment. In this model, the human population is divided into four classes, namely susceptible, exposed, infected, and recovered. The mosquito population is divided into three classes, namely susceptible, exposed and infected. Furthermore, the reproduction number $\left(R_{0}\right)$ is constructed, which is the expected number of infections per unit of time. $R_{0}$ in this article is determined by using a next-generation matrix approach. At the end of this article is provided numerical simulations to show the effectiveness of vaccination and treatment in humans to suppress the rate of transmission of disease. The simulation results show that the increase of vaccination effectiveness and treatment in humans can reduce the reproduction number. It shows that the number of infected individuals is decreasing and within a certain time the disease will disappear from the population.
\end{abstract}

Keywords : Reproduction Numbers, Malaria Model, SEIRS-SEI, Vaccination, Medication.

2000 Mathematics Subject Classification: 93A30

Received: 2017-06-01, accepted: 2017-07-17. 


\section{INTRODUCTION}

Malaria merupakan penyakit yang disebabkan oleh infeksi parasit dari Nyamuk Anopheles betina genus Plasmodium. Malaria dapat ditularkan melalui gigitan nyamuk yang terinfeksi, transfusi darah, pemakaian jarum suntik, maupun bawaan. Malaria tergolong penyakit yang sangat mematikan bagi manusia. Oleh karena itu, diperlukan perlakuan pencegahan untuk mengendalikannya baik tingkat infeksi maupun tingkat penyebaran penyakit ini. Berdasarkan beberapa kasus malaria yang telah terjadi, muncul berbagai penelitian yang mengontruksikan sebuah model matematika untuk malaria. Pemodelan matematika dapat membantu memahami dan mengidentifikasi hubungan penyebaran penyakit malaria dengan berbagai parameter epidemiologi, membantu dalam perencanaan masa depan dan mempertimbangkan langkahlangkah pengendalian yang tepat.

Dalam penelitian ini dibahas sebuah model penyebaran malaria yang dikembangkan oleh Laarabi et al., [6] dan Putri et al. [8]. Modifikasi model dilakukan dengan penambahan kelas terpapar (exposed) pada kedua populasi dengan mengacu pada Chitnis et al. [3]. Hal ini diperlukan karena sporozoid yang dihasilkan dari gigitan nyamuk terinfeksi memerlukan masa inkubasi selama 9-14 hari untuk benar-benar menimbulkan penyakit (Bloland and Williams, [2]). Selama masa inkubasi ini, populasi dikelompokkan ke dalam kelas terpapar (exposed), sehingga model ini disebut SEIRS-SEI. Modifikasi model juga dilakukan dengan penambahan parameter perlakuan berupa vaksinasi pada manusia. Vaksinasi yang diberikan dapat membuat manusia rentan yang telah tergigit dapat langsung berpindah ke manusia pulih. Dalam hal ini diasumsikan bahwa manusia pada kelas rentan $\left(S_{h}\right)$ dapat berpindah ke kelas pulih $\left(R_{h}\right)$ karena adanya vaksinasi dengan laju $\theta$ (Schwartz et al., [9]). Tujuan dari penelitian ini adalah untuk mengonstruksi bilangan reproduksi $\left(R_{h}\right)$ yang merupakan nilai harapan banyaknya infeksi tiap satuan waktu. $R_{0}$ ditentukan dengan menggunakan pendekatan matriks generasi mendatang (Diekmann et al., [4] dan van den Driessche and Watmough, [10]). Selanjutnya akan dilakukan simulasi dengan komputasi numerik untuk melihat efektifitas vaksinasi dan pengobatan pada manusia untuk menekan laju penularan penyakit.

\section{Model Matematika}

Secara skematis, pola penyebaran penyakit malaria pada model ini dapat digambarkan dalam diagram kompartemen pada Gambar 1

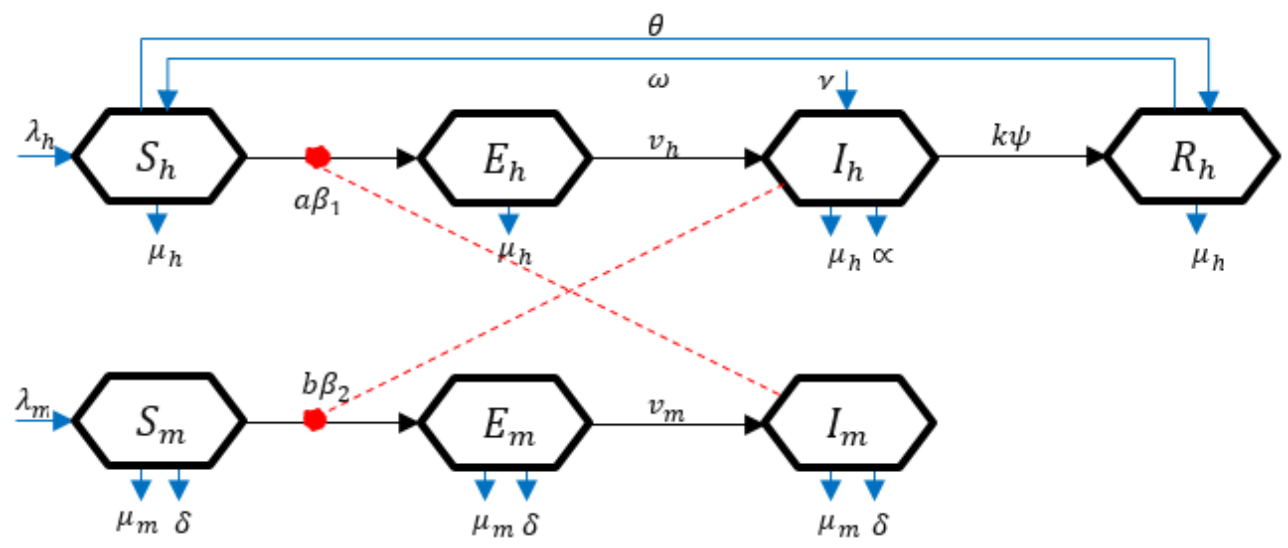

GAMBAR 1. Diagram kompartemen penyakit malaria tipe SEIRS-SEI dengan vaksinasi dan pengobatan 
Dengan demikian, persamaan dinamika sistem tersebut diformulasikan sebagai berikut :

$$
\left\{\begin{array}{l}
\frac{d S_{h}}{d t}=\lambda_{h}+\omega R_{h}-\alpha \beta_{1} I_{m} S_{h}-\left(\theta+\mu_{h}\right) S_{h} \\
\frac{d E_{h}}{d t}=\alpha \beta_{1} I_{m} S_{h}-\left(v_{h}+\mu_{h}\right) E_{h} \\
\frac{d I_{h}}{d t}=v_{h} E_{h}+\gamma I_{h}-\left(\mu_{h}+\alpha+k \psi\right) I_{h} \\
\frac{d R_{h}}{d t}=k \Psi I_{h}-\left(\mu_{h}+\omega\right) R_{h}+\theta S_{h} \\
\frac{d S_{m}}{d t}=\lambda_{m}-\left(b \beta_{2} I_{h}+\mu_{m}+\delta\right) S_{m} \\
\frac{d E_{m}}{d t}=b \beta_{2} I_{h} S_{m}-\left(v_{m}+\mu_{m}+\delta\right) E_{m} \\
\frac{I_{m}}{d t}=v_{m} E_{m}-\left(\mu_{m}+\delta\right) I_{m}
\end{array}\right.
$$

Variabel dan parameter yang digunakan disajikan pada Tabel 1 dan Tabel 2.

TABEL 1. Variabel pada model malaria tipe SEIRS-SEI dengan vaksinasi dan pengobatan

\begin{tabular}{cc}
\hline Variabel & Keterangan \\
\hline$S_{h}(t)$ & Banyaknya manusia yang rentan terkena penyakit malaria pada waktu t \\
$E_{h}(t)$ & Banyaknya manusia yang terpapar penyakit malaria pada waktu t \\
$I_{h}(t)$ & Banyaknya manusia yang terinfeksi penyakit malaria pada waktu t \\
$R_{h}(t)$ & Banyaknya manusia yang sembuh dari penyakit malaria pada waktu t \\
$S_{m}(t)$ & Banyaknya nyamuk yang rentan terkena penyakit malaria pada waktu t \\
$E_{m}(t)$ & Banyaknya nyamuk yang terpapar penyakit malaria pada waktu t \\
$I_{m}(t)$ & Banyaknya nyamuk yang terinfeksi penyakit malaria pada waktu t \\
\hline
\end{tabular}

TABEL 2. Parameter pada model malaria tipe SEIRS-SEI dengan vaksinasi dan pengobatan

\begin{tabular}{|c|c|c|}
\hline Parameter & Keterangan & Satuan \\
\hline$\lambda_{h}$ & Laju kelahiran dan migrasi manusia & orang $\mathrm{x}$ waktu ${ }^{-1}$ \\
\hline$\lambda_{m}$ & Laju kelahiran dan migrasi nyamuk & nyamuk x waktu ${ }^{-1}$ \\
\hline$\mu_{h}$ & Laju konstan kematian manusia secara alami & waktu $^{-1}$ \\
\hline$\mu_{m}$ & Laju konstan kematian nyamuk secara alami & waktu $^{-1}$ \\
\hline$a$ & $\begin{array}{l}\text { Rata-rata banyaknya gigitan nyamuk terinfeksi } \\
\text { pada manusia rentan tiap satuan waktu }\end{array}$ & nyamuk x waktu ${ }^{-1}$ \\
\hline$b$ & $\begin{array}{l}\text { Rata-rata banyaknya gigitan nyamuk rentan } \\
\text { pada manusia terinfeksi tiap satuan waktu }\end{array}$ & orang $\mathrm{x}$ waktu ${ }^{-1}$ \\
\hline$\beta_{1}$ & $\begin{array}{l}\text { Peluang terjadinya transmisi penyakit } \\
\text { dari nyamuk terinfeksi ke manusia rentan }\end{array}$ & tanpa satuan \\
\hline$\beta_{2}$ & $\begin{array}{l}\text { Peluang terjadinya transmisi penyakit dari } \\
\text { manusia terinfeksi ke nyamuk rentan }\end{array}$ & tanpa satuan \\
\hline$\delta$ & Efektivitas penyemprotan pada nyamuk & waktu $^{-1}$ \\
\hline$\omega$ & $\begin{array}{l}\text { Laju konstan hilangnya kekebalan tubuh } \\
\text { pada manusia setelah pulih }\end{array}$ & waktu $^{-1}$ \\
\hline$\theta$ & Efektivitas vaksinasi pada manusia & waktu $^{-1}$ \\
\hline$\gamma$ & Laju bayi yang lahir dari ibu yang terinfeksi Malaria & waktu $^{-1}$ \\
\hline$\psi$ & Efektivitas pengobatan pada manusia & tanpa satuan \\
\hline$\alpha$ & Laju kematian manusia akibat malaria & waktu ${ }^{-1}$ \\
\hline$k$ & Laju pemulihan manusia & waktu $^{-1}$ \\
\hline$v_{h}$ & Laju perpindahan manusia terpapar ke manusia terinfeksi & waktu $^{-1}$ \\
\hline$v_{m}$ & Laju perpindahan nyamuk terpapar ke nyamuk terinfeksi & waktu $^{-1}$ \\
\hline
\end{tabular}




\section{TITIK TETAP}

Titik tetap diperoleh dengan menyelesaikan sistem (1), yaitu kondisi yang diperoleh pada saat $\frac{d S_{h}}{d t}=\frac{d E_{h}}{d t}=\frac{d I_{h}}{d t}=\frac{d R_{h}}{d t}=\frac{d S_{m}}{d t}=\frac{d E_{m}}{d t}=\frac{d I_{m}}{d t}=0$ Dari persamaan (1), diperoleh titik tetap bebas penyakit (disease - freeequilibrium),

$$
x_{d f e}=\left(S_{h}, E_{h}, I_{h}, R_{h}, S_{m}, E_{m}, I_{m}\right)=\left(S_{h}^{*}, 0,0, R_{h}^{*}, S_{m}^{*}, 0,0\right)
$$

dengan

$$
S_{h}^{*}=\frac{\lambda_{h}\left(\omega+\mu_{h}\right)}{\mu_{h}\left(\mu_{h}+\omega+\theta\right)}, R_{h}^{*}=\frac{\theta \lambda_{h}}{\mu_{h}\left(\mu_{h}+\omega+\theta\right)}=S_{m}^{*}=\frac{\lambda_{m}}{\delta+\mu_{m}}
$$

\section{Konstruksi Bilangan Reproduksi}

Bilangan reproduksi yang dinotasikan dengan $R_{0}$ adalah nilai harapan banyaknya infeksi tiap satuan waktu. Infeksi ini terjadi pada suatu populasi rentan yang dihasilkan oleh satu individu terinfeksi. Berdasarkan sistem persamaan (1), diambil sistem persamaan yang memuat populasi terpapar dan terinfeksi, yaitu

$$
\left\{\begin{array}{l}
\frac{d E_{h}}{d t}=\alpha \beta_{1} I_{m} S_{h}-\left(v_{h}+\mu_{h}\right) E_{h} \\
\frac{d I_{h}}{d t}=v_{h} E_{h}+\gamma I_{h}-\left(\mu_{h}+\alpha+k \psi\right) I_{h} \\
\frac{d E_{m}}{d t}=b \beta_{2} I_{h} S_{m}-\left(v_{m}+\mu_{m}+\delta\right) E_{m} \\
\frac{I_{m}}{d t}=v_{m} E_{m}-\left(\mu_{m}+\delta\right) I_{m}
\end{array}\right.
$$

Berdasarkan sistem persamaan (4), diperoleh matriks $F$ dan $V$ sebagai berikut

$$
F=\left[\begin{array}{c}
\alpha \beta_{1} I_{m} S_{h} \\
b \beta_{2} I_{h} S_{m}
\end{array}\right] \quad V=\left[\begin{array}{c}
\mu_{h} E_{h}+\left(\mu_{h}+\alpha+k \psi-\gamma\right) I_{h} \\
\left(\mu_{m}+\delta\right) E_{m}+\left(\mu_{m}+\delta\right) I_{m}
\end{array}\right]
$$

Matriks Jacobian dari persamaan (5) dinyatakan dengan matriks $F=J(F)$ dan $V=$ $J(V)$, sehingga diproleh

$$
F=\left[\begin{array}{cc}
0 & \alpha \beta_{1} S_{h} \\
b \beta_{2} S_{m} & 0
\end{array}\right] \text { dan } V=\left[\begin{array}{cc}
\mu_{h}+\alpha+k \psi-\gamma & 0 \\
0 & \mu_{m}+\delta
\end{array}\right]
$$

Selanjutnya dengan subtitusi titik tetap bebas penyakit (2) pada persamaan (6), diperoleh

$$
F=\left[\begin{array}{cc}
0 & \frac{\alpha \beta_{1} \lambda_{h}\left(\omega+\mu_{h}\right)}{\mu_{h}\left(\mu_{h}+\omega+\theta\right)} \\
\frac{b \beta_{2} \lambda_{m}}{\delta+\mu_{m}} & 0
\end{array}\right] \text { dan } V=\left[\begin{array}{cc}
\mu_{h}+\alpha+k \psi-\gamma & 0 \\
0 & \mu_{m}+\delta
\end{array}\right]
$$

Matriks next generation (K) didefinisikan berdasarkan persamaan (7) dengan $K=F V^{-1}$, yaitu

$$
K=\left[\begin{array}{cc}
0 & \frac{\alpha \beta_{1} \lambda_{h}\left(\omega+\mu_{h}\right)}{\mu_{h}\left(\mu_{h}+\omega+\theta\right)\left(\mu_{m}+\delta\right)} \\
\frac{b \beta_{2} \lambda_{m}}{\left(\delta+\mu_{m}\right)\left(\mu_{h}+\alpha+k \psi-\gamma\right)} & 0
\end{array}\right]
$$

Selanjutnya matriks $\mathrm{K}$ dinyatakan dengan

$$
K=\left[\begin{array}{cc}
0 & K_{2} \\
K_{1} & 0
\end{array}\right]
$$

dimana

$$
K_{1}=\frac{b \beta_{2} \lambda_{m}}{\left(\delta+\mu_{m}\right)\left(\mu_{h}+\alpha+k \psi-\gamma\right)} \text { dan } \quad K_{2}=\frac{\alpha \beta_{1} \lambda_{h}\left(\omega+\mu_{h}\right)}{\mu_{h}\left(\mu_{h}+\omega+\theta\right)\left(\mu_{m}+\delta\right)}
$$

Bilangan reproduksi $R_{0}$ merupakan nilai eigen positif terbesar dari matriks $K=F V^{-1}$, yaitu

$$
R_{0}=\rho(K) ; \rho=\text { Nilai Eigen Dominan }
$$


Untuk menentukan nilai eigen dari matriks K, dituliskan bentuk persamaan karakteristik dari matriks K, yaitu

$$
\operatorname{det}(K-\xi I)=0 ; \xi=\text { Nilai Eigen, }
$$

sehingga diperoleh

$$
\xi= \pm \sqrt{K_{1} K_{2}}
$$

Dengan demikian, dapat ditentukan nilai eigen dengan modulus terbesar matriks K, yaitu

$$
R_{0}=\max _{i}\left|\xi_{i}\right|, i=1,2,
$$

sehingga diperoleh bilangan reproduksi

$$
R_{0}=\sqrt{K_{1} K_{2}}
$$

dimana dimana $K_{1}$ dan $K_{2}$ dinyatakan pada persamaan (10).

Persamaan (15) merupakan nilai ambang batas epidemik yang akan menjadi tolak ukur tingkat penyebaran malaria dalam populasi. Kondisi yang memungkinkan dari bilangan reproduksi menurut van den Driessche \& Watmough [10] adalah:

(1) Jika $R_{0}<1$, maka jumlah individu yang terinfeksi akan menurun pada setiap generasi, sehingga penyakit akan menghilang.

(2) Jika $R_{0}>1$, maka jumlah individu yang terinfeksi akan meningkat pada setiap generasi, sehingga penyakit akan meningkat dan mewabah.

\section{Simulasi Numerik}

5.1. Nilai Parameter. Pada bagian simulasi ini, diamati dinamika populasi dalam kondisi ketika $R_{0}<1$. Dalam hal ini, $R_{0}$ merupakan bilangan reproduksi yang didefinisikan pada persamaan (15). Simulasi dilakukan untuk menunjukkan adanya pengaruh treatment berupa pengobatan dan vaksinasi pada manusia terhadap dinamika populasi manusia dan populasi nyamuk. Pemilihan parameter didasarkan pada studi yang dilakukan oleh berbagai sumber terpercaya. Beberapa nilai parameter seperti yang menyangkut populasi, didasarkan pada

\begin{tabular}{|c|c|c|c|}
\hline Parameter & Nilai Parameter & Satuan & Sumber \\
\hline$\lambda_{h}$ & 0.027 & orang $\mathrm{x}$ hari $^{-1}$ & Agusto et al., [1] \\
\hline$\lambda_{m}$ & 0.13 & nyamuk x hari ${ }^{-1}$ & Agusto et al., [1] \\
\hline$\mu_{h}$ & 0.004 & hari $^{-1}$ & Agusto et al., [1] \\
\hline$\mu_{m}$ & 0.04 & -1 & Agusto et al., [1] \\
\hline$a$ & 4.3 & nyamuki-1 & Labadin et al., [7] \\
\hline$b$ & 0.33 & $\mathrm{x}$ hari $^{-1}$ & Johansson and Leander, [5] \\
\hline$\beta_{1}$ & 0.010 & orang $^{-1} \mathrm{x}$ hari $^{-1}$ & Chitnis et al., [3] \\
\hline$\beta_{2}$ & 0.072 & tanpa satuan & Chitnis et al., [3] \\
\hline$\delta$ & 0.01 & tanpa satuan & Asumsi \\
\hline$\omega$ & $1 / 730$ & tanpa satuan & Agusto et al., [1] \\
\hline$\theta$ & 0.1 & hari $^{-1}$ & Asumsi \\
\hline$\gamma$ & 0.005 & tanpa satuan & Asumsi \\
\hline$\psi$ & 0.1 & tanpa satuan & Asumsi \\
\hline$\alpha$ & 0.005 & hari $^{-1}$ & Agusto et al., [1] \\
\hline$k$ & 0.611 & hari $^{-1}$ & Laarabi et al., $[6]$ \\
\hline$v_{h}$ & 0.1 & hari $^{-1}$ & Labadin et al., $[7]$ \\
\hline$v_{m}$ & 0.083 & hari $^{-1}$ & Johansson and Leander [5] \\
\hline
\end{tabular}
asumsi tentang situasi penyakit yang paling umum dan disajikan pada Tabel 3.

TABEL 3. Parameter pada model malaria tipe SEIRS-SEI dengan vaksinasi dan pengobatan

Simulasi dilakukan dengan menggunakan nilai parameter pada Tabel 3, dengan nilai awal populasi manusia rentan $\left(S_{h}\right)$ adalah 300 , populasi manusi terpapar $\left(E_{h}\right)$ adalah 50 , populasi 
manusia terinfeksi $\left(I_{h}\right)$ adalah 10 , populasi manusi pulih $\left(R_{h}\right)$ adalah 0 , populasi nyamuk rentan $\left(S_{m}\right)$ adalah 2000 , populasi nyamuk terpapar $\left(E_{m}\right)$ adalah 100 dan populasi nyamuk terinfeksi $\left(I_{m}\right)$ adalah 50 .

5.2. Simulasi Efektifitas Pengobatan pada Manusia. Pada bagian ini, dilakukan simulasi untuk menunjukkan adanya kontribusi pengobatan pada manusia dalam menekan laju penularan penyakit. Dalam hal ini, dilakukan perubahan pada paramater efektifitas pengobatan pada manusia $(\psi)$. Akan ditunjukkan bahwa perubahan nilai pada parameter $\psi$ dapat mengubah nilai bilangan reproduksi $\left(R_{0}\right)$ yang didefinisikan pada persamaan (15). Terdapat tiga nilai $\psi$ yang diamati, diambil pada selang $[0.10,0.50]$ dengan langkah 0.20 . Adapun nilai-nilai parameter lain dapat dilihat pada Tabel 3. Perubahan nilai parameter $\psi$ yang menyebabkan terjadinya perubahan nilai bilangan reproduksi dapat dilihat pada Tabel 4.

TABEL 4. Hasil simulasi efektifitas pengobatan pada manusia terhadap bilangan reproduksi

\begin{tabular}{cc}
\hline Parameter $\psi$ & Bilangan reproduksi \\
\hline$\psi=0.10$ & $R_{0}=0.53$ \\
$\psi=0.30$ & $R_{0}=0.31$ \\
$\psi=0.50$ & $R_{0}=0.24$ \\
\hline
\end{tabular}

Pada populasi manusia yang ditunjukkan pada Gambar 2. Jika efektifitas pengobatan pada manusia ditingkatkan, maka banyaknya manusia terpapar dan terinfeksi mengalami penurunan, sementara manusia yang pulih dari penyakit mengalami peningkatan.
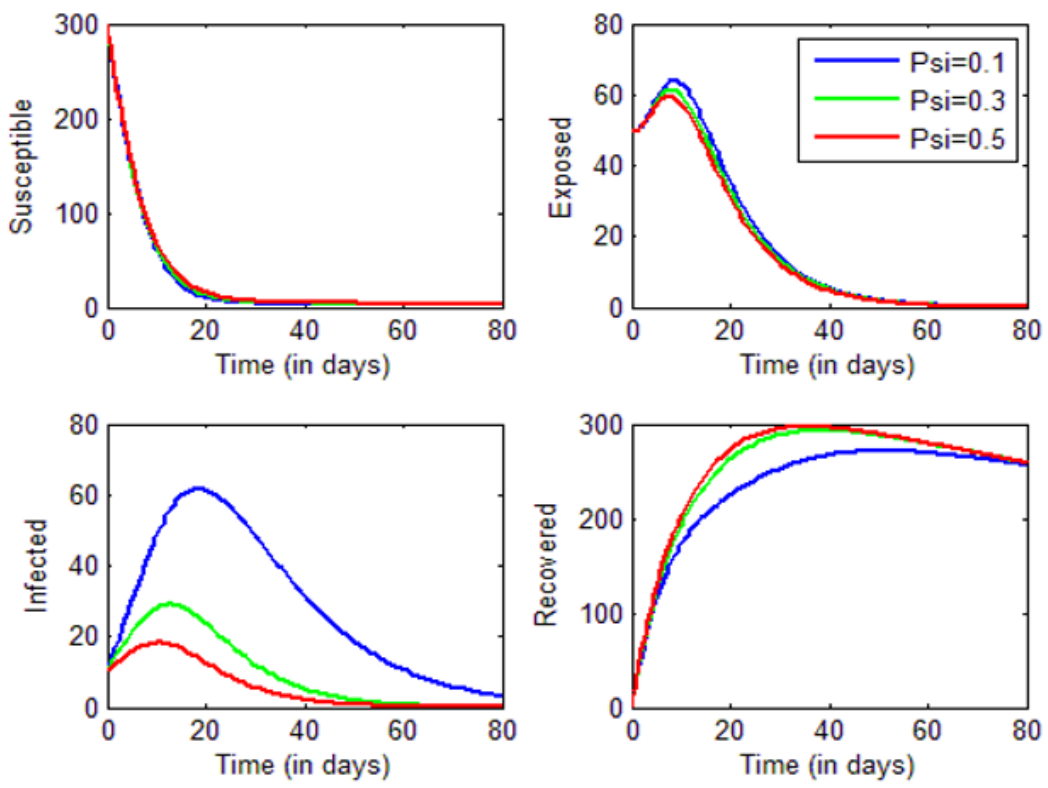

GAMBAR 2. Dinamika populasi manusia karena adanya pengobatan

Pengobatan yang diberikan pada manusia juga berdampak pada populasi nyamuk, sebagaimana ditunjukkan pada Gamba 3. Jika efektifitas pengobatan pada manusia ditingkatkan, maka populasi nyamuk pada kelas terpapar dan terinfeksi mengalami penurunan. Hal ini menyebabkan jumlah nyamuk pada populasi rentan mengalami peningkatan.

Adanya perubahan jumlah manusia dan nyamuk pada masing-masing kelas subpopulasi cenderung berbeda untuk setiap kenaikan efektifitas pengobatan pada manusia. Maksimum 

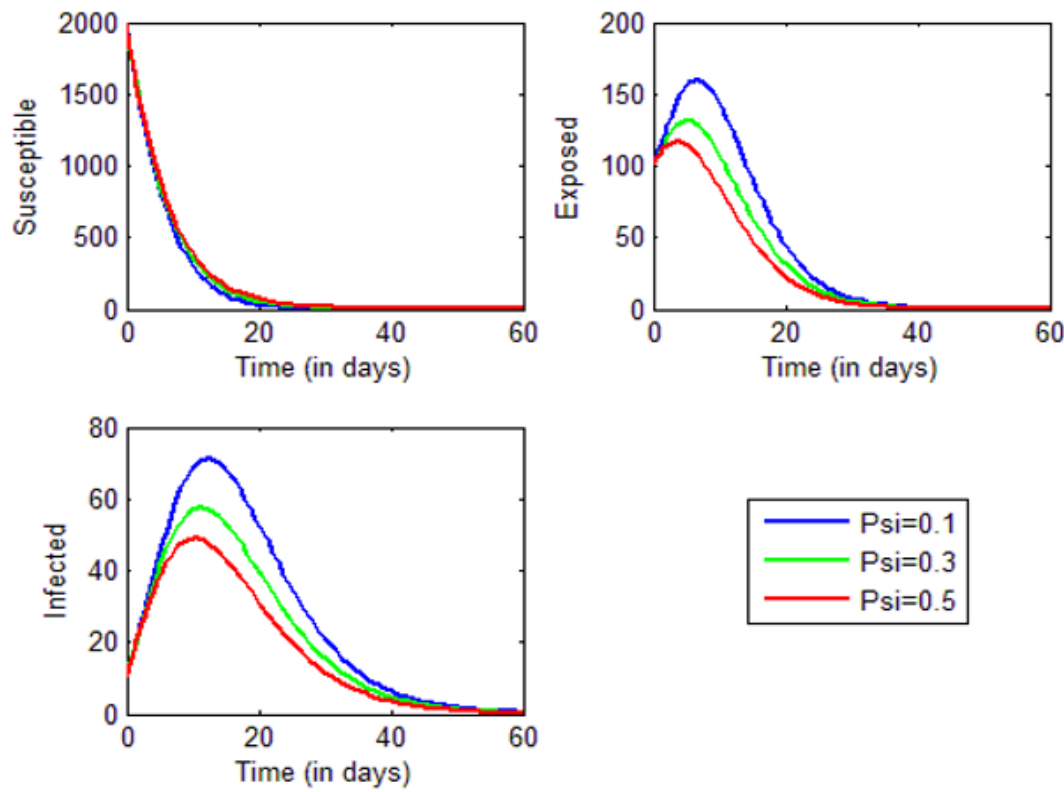

GAmbar 3. Dinamika populasi nyamuk karena adanya pengobatan pada manusia

banyaknya manusia dan nyamuk terpapar terjadi pada sekitar hari ke-9, sementara maksimum banyaknya manusia dan nyamuk terinfeksi terjadi pada hari ke-20 dan ke-15. Hal ini sejalan dengan teori bahwa manusia yang terpapar akan mengalami masa inkubasi selama kurang lebih 14 hari kemudian benar-benar terinfeksi. Pada hari ke-20, dengan efektifitas pengobatan pada manusia ditingkatkan sebesar $40 \%$ dapat menurunkan populasi manusia terinfeksi sebesar $13,88 \%$ dari total populasi manusia dan dengan efektifitas pengobatan yang sama, pada hari ke-15 dapat menurunkan populasi nyamuk terinfeksi sebesar $1.43 \%$ dari total populasi nyamuk.

Efektifitas pengobatan dalam menekan laju penularan penyakit ditunjukkan dengan dinamika populasi pada setiap sub kelas populasi. Dengan asumsi awal populasi sebagaimana yang disebutkan pada sub bagian 5.1, terlihat peningkatan efektifitas pengobatan tidak berpengaruh secara signifkan pada populasi rentan. Hal ini disebabkan karena perlakuan pengobatan tidak dilakukan secara langsung pada populasi rentan. Perubahan signifikan terjadi pada populasi manusia terinfeksi dimana penigkatan efektifitas pengobatan mempercepat laju penurunan manusia terinfeksi. Dengan efektifitas pengobatan sebesar 10\%, manusia terinfeksi mencapai 60 orang pada hari ke-20 kemudian mengalami penurunan hingga menjapai titik nol setelah melewati hari ke-80. Setelah dilakukan peningkatan efektifitas pengobatan hingga 50\%, populasi manusia terinfeksi hanya mencapai 15 orang pada hari ke-10 kemudian mengalami penurunan hingga mencapai titik nol pada hari ke-60. Dinamika ini berlaku sama pada populasi nyamuk dimana peningkatan efektifitas pengobatan pada manusia dapat menurunkan jumlah nyamuk terinfeksi dalam waktu yang lebih cepat. Hal ini menunjukkan bahwa peningkatan efektifitas pengobatan dapat mempercepat hilangnya penyakit dalam populasi.

5.3. Simulasi Efektifitas Vaksinasi pada Manusia. Pada bagian ini, dilakukan simulasi untuk menunjukkan adanya kontribusi vaksinasi pada manusia dalam menekan laju penularan penyakit. Dalam hal ini, dilakukan perubahan pada paramater efektifitas vaksinasi pada manusia $(\theta)$. Akan ditunjukkan bahwa perubahan nilai pada parameter $\theta$ dapat mengubah nilai bilangan reproduksi $\left(R_{0}\right)$ yang didefinisikan pada persamaan (15). Terdapat tiga nilai $\theta$ yang diamati, diambil pada selang $[0.10,0.50]$ dengan langkah 0.20. Adapun nilai-nilai parameter lain dapat dilihat pada Tabel 3. Perubahan nilai parameter $\theta$ yang menyebabkan terjadinya perubahan nilai bilangan reproduksi dapat dilihat pada Tabel 5 . 
TABEL 5. Hasil simulasi efektifitas vaksinasi pada manusia terhadap bilangan reproduksi

\begin{tabular}{cc}
\hline Parameter $\theta$ & Bilangan reproduksi \\
\hline$\theta=0.10$ & $R_{0}=0.53$ \\
$\theta=0.30$ & $R_{0}=0.31$ \\
$\theta=0.50$ & $R_{0}=0.24$ \\
\hline
\end{tabular}

Pada populasi manusia yang ditunjukkan pada Gambar 4, jika efektifitas vaksinasi pada manusia ditingkatkan, maka banyaknya manusia terpapar dan terinfeksi mengalami penurunan, sementara manusia yang pulih dari penyakit mengalami peningkatan. Hal ini disebabkan karena vaksinasi menyebabkan manusia rentan kebal dari penyakit.
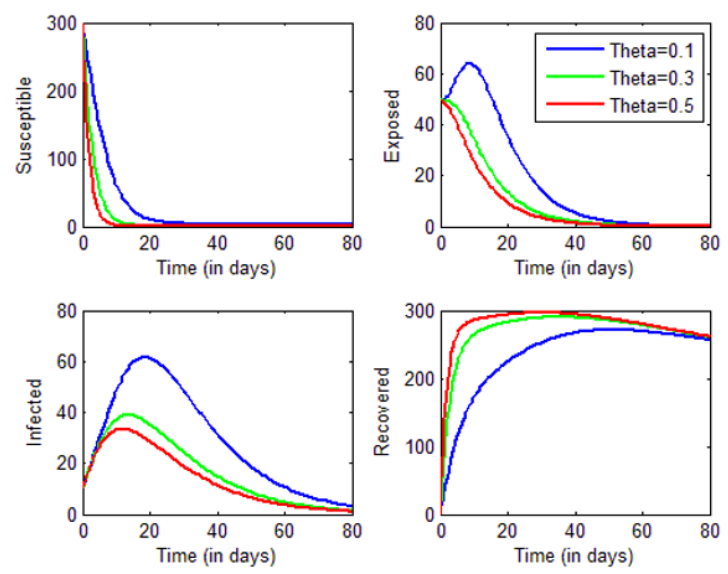

GAmbar 4. Dinamika populasi manusia karena adanya vaksinasi

Vaksinasi yang diberikan pada manusia juga berdampak pada populasi nyamuk, sebagaimana ditunjukkan pada Gambar 5. Jika efektifitas vaksinasi pada manusia ditingkatkan, maka populasi nyamuk pada kelas terpapar dan terinfeksi mengalami penurunan. Hal ini disebabkan karena vaksinasi menyebabkan manusia terinfeksi berkurang. Dengan demikian, peluang nyamuk terpapar oleh manusia terinfeksi juga berkurang.
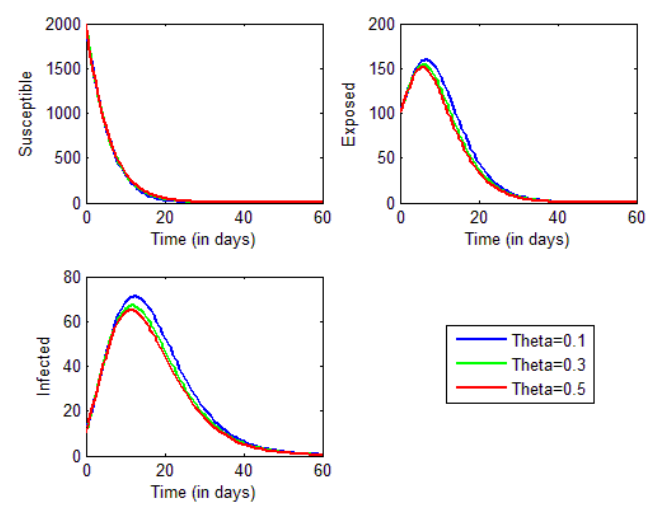

GAmBAR 5. Dinamika populasi nyamuk karena adanya vaksinasi pada manusia

Adanya perubahan jumlah manusia dan nyamuk pada masing-masing kelas subpopulasi cenderung berbeda untuk setiap kenaikan efektifitas vaksinasi pada manusia. Maksimum 
banyaknya manusia dan nyamuk terpapar terjadi pada sekitar hari ke-10, sementara maksimum banyaknya manusia dan nyamuk terinfeksi terjadi pada hari ke-20. Pada hari ke-20, dengan peningkatan efektifitas vaksinasi pada manusia sebesar $40 \%$ dapat menurunkan populasi manusia terinfeksi sebesar $12.50 \%$ dari total populasi manusia dan dapat menurunkan populasi nyamuk terinfeksi sebesar $0.47 \%$ dari total populasi nyamuk. Hal ini menunjukkan bahwa peningkatan efektifitas vaksinasi dapat mempercepat hilangnya penyakit dalam populasi. Adapun dampak vaksinasi terhadap nyamuk tidak begitu besar karena vaksinasi tidak berdampak langsung pada nyamuk. Vaksinasi hanya menurunkan jumlah manusia terinfeksi sehingga peluang nyamuk terpapar dari manusia terinfeksi menjadi lebih kecil. Efektifitas vaksinasi dalam menekan laju penularan penyakit ditunjukkan dengan dinamika populasi pada setiap sub kelas populasi. Dengan asumsi awal populasi sebagaimana yang disebutkan pada sub bagian 5.1, terlihat peningkatan efektifitas vaksinasi tidak berpengaruh secara signifkan pada populasi nyamuk. Hal ini disebabkan karena perlakuan vaksinasi tidak berdampak secara langsung pada nyamuk. Perubahan signifikan terjadi pada populasi manusia dimana penigkatan efektifitas vaksinasi mempercepat laju penurunan manusia rentan, terpapar, dan terinfeksi serta mempercepat jumlah populasi manusia sembuh. Dinamika ini terjadi karena manusia yang divaksinasi akan berpindah ke kelas manusia sembuh setelah tergigit oleh nyamuk terinfeksi. Dengan efektifitas vaksinasi sebesar 10\%, manusia terinfeksi mencapai 60 orang pada hari ke-20 kemudian mengalami penurunan hingga menjapai titik nol setelah melewati hari ke- 80 . Setelah dilakukan peningkatan efektifitas vaksinasi hingga $50 \%$, populasi manusia terinfeksi hanya mencapai 15 orang pada hari ke-10 kemudian mengalami penurunan hingga mencapai titik nol, sementara populasi manusia sembuh mengalami peningkatan secara signifikan. Hal ini menunjukkan bahwa peningkatan efektifitas vaksinasi dapat mempercepat hilangnya penyakit dalam populasi.

\section{Simpulan}

Berdasarkan hasil rekonstruksi, diperoleh rumusan bilangan reproduksi sebagaimana yang tulis pada persamaan (15). Perlakuan (treatment) yang diberikan memiliki pengaruh terhadap dinamika populasi manusia dan nyamuk yang ditunjukkan dengan bilangan reproduksi. Secara umum, jika efektivitas perlakuan ditingkatkan maka bilangan reproduksi menurun. Hal tersebut menunjukkan bahwa jumlah individu terinfeksi semakin berkurang, sehingga penyakit tidak akan menyebar dan dalam jangka waktu tertentu akan menghilang dari populasi.

\section{DAFTAR PustakA}

[1] Agusto, F.B., Marcus, N., and Okosun, K.O., 2012, Application of optimal control to the epidemiology of malaria, Electronic Journal of Differential Equation, Vol. 2012, No.81, pp. 1-22.

[2] Bloland, P.B., and Williams, H.A., 2002, Malaria Control During Mass Population Movements and Natural Disasters, Washington, The National Academies Press

[3] Chitnis, N., Chussing, J.M., and Hyman, J.M., 2006, Bifurcation Analysis of A Mathematical Model for Malaria Transmission, Siam J. Appl. Math. Vol. 67, No. 1, pp. 2445

[4] Diekmann, O., Heesterbeek, J.A.P., and Metz, J.A.J., 1990, On the Definition and the Computation of the Basic Reproduction Ratio $R_{0}$ in Models for Infectious Diseases in Heterogeneous Populations, J. Math. Biol., 28, pp. 365-382

[5] Johansson, P. and Leander, J., 2010, Mathematical Modeling of Malaria: Methods for Simulation of Epidemics, Gothenburg: Chalmers University of Technology.

[6] Laarabi, H., Labriji, E.H., Rachik, M., and Kaddar, A., 2012, Optimal Control of an Epidemic Model with A Saturated Incidence Rate, Modelling and Control, Vol.17, No.4, 448-459

[7] Labadin, C., Kon, M.L., and Juan, S.F.S., 2009, Deterministic Malaria Transmission Model with Acquired Immunity, Proceedings of the World Congress on Engineering and Computer Science 2009 Vol II, San Francisco, USA 
[8] Putri, R.G., Jaharuddin, and Bakhtiar, T., 2014, SIRS-SI Model of Malaria Disease with Application of Vaccines, Anti-Malarial Drugs, and Spraying, IOSR Journal of Mathematics (IOSR-JM), Vol.10, Issue V Ver. II

[9] Schwartz, L., Brown, G.V., Genton, B., and Moorthy, V.S., 2012, A Reiew of Malaria Vaccine Clinical Projects Based on the WHO Rainbow Table. Malaria Journal, 11:11

[10] Van den Driessche, P., Watmough, J., 2002, Reproduction numbers and sub-threshold endemic equilibria for compartmental models of disease transmission, Mathematical Biosciences, 180 (12): 2948 